\title{
Rhodium(I) complexes containing a bulky pyridinyl N-heterocyclic carbene ligand: Preparation and reactivity
}

\author{
Chao-Yu Wang, Yi-Hong Liu, Shei-Ming Peng, Shiuh-Tzung Liu * \\ Department of Chemistry, National Taiwan University, Taipei 106, Taiwan, ROC
}

Received 25 March 2006; received in revised form 1 June 2006; accepted 2 June 2006

Available online 15 June 2006

\begin{abstract}
Coordination chemistry of a new pyridine imidazole-2-ylidene ligand ( $\mathrm{pyN}^{\wedge} \mathrm{C}$ ) system with sterically hindered substituents toward rhodium(I) metal ions has been investigated. The rhodium complex $\left[\left(\right.\right.$ pyN $\left.\left.^{\wedge} \mathrm{C}\right) \mathrm{RhCl}(\mathrm{COD})\right](\mathrm{COD}=1,5$-cyclooctadiene $)$ was prepared via the transmetallation from the silver complex $\left[\left(C \text {-pyN }{ }^{\wedge} \mathrm{C}\right)_{2} \mathrm{Ag}\right] \mathrm{AgI} \mathrm{I}_{2}$. Upon the abstraction of chloride, the pyridinyl nitrogen coordinated to the metal center and formed $\left[\left(C, N-\right.\right.$ py $\left.\left.\mathrm{N}^{\wedge} \mathrm{C}\right) \mathrm{Rh}(\mathrm{COD})\right] \mathrm{BF}_{4}$ with the chelation of $\mathrm{pyN}^{\wedge} \mathrm{C}$. The pyridinyl nitrogen donor was found to be labile and could be replaced by various donors such as phosphine, azide and halides. Substitution of COD by various donors does not proceed except strong $\pi$-acid ligands such as $\mathrm{CO}$ and $\mathrm{P}\left(\mathrm{OCH}_{3}\right)_{3}$. However, the chelation of pyN $\mathrm{N}^{\wedge}$ was replaced by the bisphosphine $(\mathrm{P} \sim \mathrm{P})$ to form $\left[(\mathrm{P} \sim \mathrm{P})_{2} \mathrm{Rh}\right] \mathrm{BF}_{4}$, which was subsequently oxidized to yield $\left[(\mathrm{P} \sim \mathrm{P})_{2} \mathrm{Rh}\left(\mathrm{O}_{2}\right)\right] \mathrm{BF}_{4}$.
\end{abstract}

(C) 2006 Elsevier B.V. All rights reserved.

Keywords: Carbene; Rhodium; Substitution; Coordination

\section{Introduction}

Since the stable diaminocarbene was first isolated by Arduengo [1], the chemistry involving this type of carbenes has been attracted considerable attention [2-13]. These carbenes are considered as an important class of ligands with strong basicity and good $\sigma$-donating properties. Thus, transition metal complexes containing N-heterocylic carbene moiety were found to be thermally stable and less sensitive toward dioxygen as compared to those with phosphine ligands [7].

Regarding chelate-carbene ligands, quite a few heterofunctionalized diaminocarbene ligands are known [1012]. Amongst, Cavell and coworkers have demonstrated that the chelation effect of the pyridinyl imidazole-2-ylidene ligand $\mathbf{1}$ toward palladium ions is due to the presence of a strong coordinating pyridinyl donor [9].

\footnotetext{
${ }^{*}$ Corresponding author. Tel.: +88622366 0352; fax: +886223636359. E-mail address: stliu@ntu.edu.tw (S.-T. Liu).
}

Furthermore, the carbene ligand with a steric bulky substituent on the imidazole ring makes the coordination environment more versatile $[9,10]$. It has been shown that $\mathrm{Rh}(\mathrm{I})$ complexes with a bulky carbene moiety underwent $\mathrm{C}-\mathrm{H}$ activation on the substituent of ligand itself to form a Rh(III) species [9]. However, bidentate ligands with sterically hindered groups on both pyridine and imidazole rings such as $\mathbf{2}$ have less examined [9]. In view of these background, studies on the synthesis of pyridinyl-carbene precursor 3, preparation of the corresponding rhodium complexes and their reactivities toward various donors were investigated.<smiles>[R]N1C=CN(Cc2ccccn2)C1</smiles>

1<smiles>[R]c1cccc(CN2[C]N([R])C=C2)n1</smiles>

$\mathrm{R}^{\prime}$ : bulky substituents

2

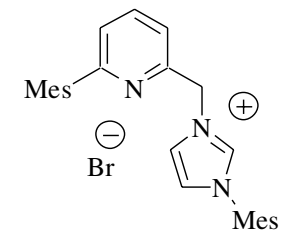

Mes= 2, 4,6-trimethylphenyl
3 


\section{Results and discussion}

\subsection{Synthesis of ligands and silver complexes}

The synthetic approach leading to pyridinyl-imidazolium salt 3 is shown in Scheme 1. Mesityl substituted pyridine-aldehyde 4 was prepared in $90 \%$ yield from the coupling of mesitylboronic acid with 6-bromopyridine-2carbaldehyde in the presence of $\mathrm{Pd}\left(\mathrm{PPh}_{3}\right)_{4}$ as the catalyst. Subsequent functional groups transformation provided the desired imidazolium salt $\mathbf{3}$ with mesityl substituents. The imidazolium salt $\mathbf{3}$ as well as the intermediates leading to it were characterized by both spectroscopic and elemental analyses.

Deprotonation of imidazolium salt 3 with $n$-BuLi to produce the corresponding carbene (denoted as $\mathrm{pyN}^{\wedge} \mathrm{C}$ ) did not succeed presumably due to the interference of the deprotonation of benzylic methylene protons [9]. Alternatively the carbene transfer method was employed to prepare the desired metal complexes (Scheme 2) $[8,14]$. First the imidazolium salt $\mathbf{3}$ was converted into the silver carbene complex 5 [15]. In comparison with the related species, this reaction took much longer reaction time for completion, indicating that the bulky substituents readily slowed down the formation of carbene complexes. Characterization of this silver carbene complex was based on both spectroscopic data and elemental analysis. ${ }^{13} \mathrm{C}\left\{{ }^{1} \mathrm{H}\right\}$ NMR spectrum of the silver complex showed a characteristic shift for $\mathrm{Ag}-\mathrm{C}_{\text {(carbene) }}$ at $\delta$ 183.5, which was assigned to the $2 C$-imidazol-2-ylidene(carbene) carbon [16]. From the observation of $\mathrm{m} / z=897.4\left({ }^{107} \mathrm{Ag}\right)$ and $899.5\left({ }^{109} \mathrm{Ag}\right)$ on the FABMass spectrum clearly illustrated the formation of $\mathrm{Ag}(\mathrm{I})$ bis(carbene) complex, which had the same stoichiometry as those reported species [15]. Elemental analysis of the complex also suggested the formula of (C-py $\left.\mathrm{N}^{\wedge} \mathrm{C}\right)_{2} \mathrm{Ag}{ }^{\prime \prime} \mathrm{AgI}_{2}$, but the crystallization of the complex in $\mathrm{CH}_{2} \mathrm{Cl}_{2}$ /hexane gave the X-ray suitable crystals in the formula of $\left(C \text {-pyN }{ }^{\wedge} \mathrm{C}\right)_{2} \mathrm{AgI}$, a substitution of $\left[\mathrm{AgI}_{2}\right]^{-}$by the iodide anion.

Fig. 1 displays the ORTEP plot of the silver carbene complex $\left(C \text {-pyN }{ }^{\wedge} \mathrm{C}\right)_{2} \mathrm{AgI}$. The angle of $\mathrm{C}(1)-\mathrm{Ag}-\mathrm{C}(28)$ $\left[160.7(2)^{\circ}\right]$ is much deviated from the linear geometry, which is smaller than those of the reported species such as [1,3-dimesityl(imidazol-2-ylidene) $]_{2} \mathrm{Ag}^{+}\left[176.3(2)^{\circ}\right][15]$.

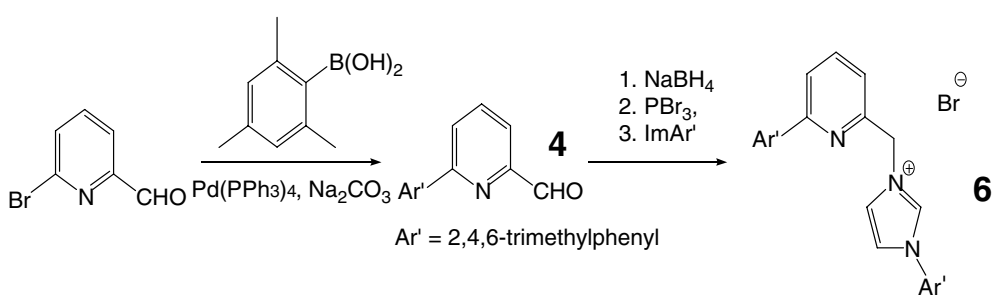

Scheme 1. Ligand preparation.

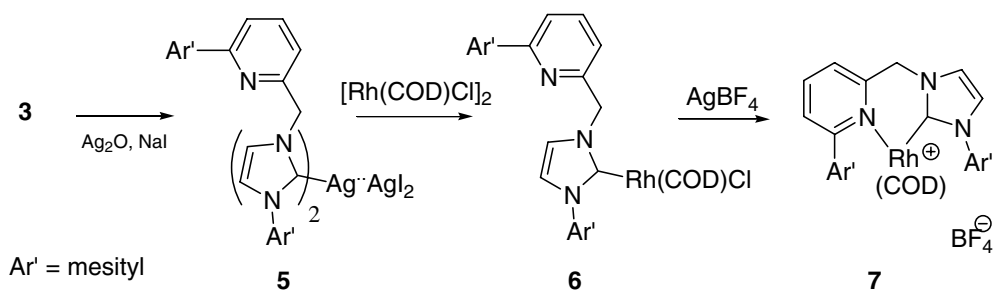

Scheme 2. Preparation of rhodium carbene complexes.

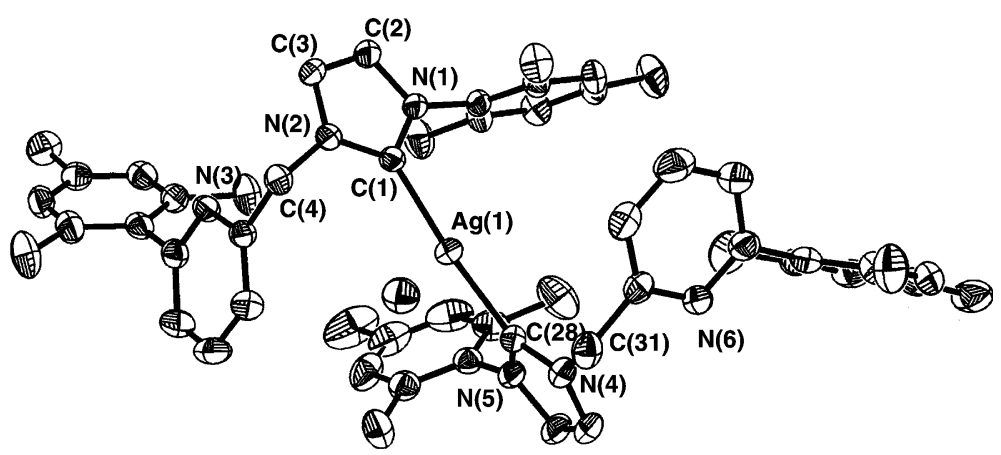

Fig. 1. ORTEP plot of $\left(C\right.$-pyN^C) ${ }_{2}$ AgI. (30\% probability ellipsoids). $\operatorname{Ag}(1)-C(1) 2.108(4) \AA, A g(1)-C(28) 2.117(4) \AA, C(1)-A g(1)-C(28) 160.7(2)^{\circ}$. 
The angle between the two planes, defined by two imidazol2-ylidene rings, is $77.07^{\circ}$, whereas the dihedral angles formed between the plane of the picolyl and imidazol-2-ylidene rings are $77.62^{\circ}$ and $76.66^{\circ}$, respectively. These observations might be a result from the relief of the steric interaction of the bulky substituents. Distances of $\mathrm{Ag}-\mathrm{C}$ are 2.108(4) and 2.117(4) $\AA$, similar to those of related species. All other bond lengths and angles are expected.

\subsection{Rhodium carbene complexes}

Treatment of $[\mathrm{Rh}(\mathrm{COD}) \mathrm{Cl}]_{2}$ with silver carbene complex 5 in dichloromethane at ambient temperature gave the desired rhodium complex $\mathbf{6}$ as yellow crystalline solids in quantitative yield (Scheme 2). The structure of this rhodium complex was determined by both spectroscopic and $\mathrm{X}$-ray crystal structural analyses. A signal of doublet at $182.0\left(J_{\mathrm{Rh}-\mathrm{C}}=51 \mathrm{~Hz}\right)$ on the ${ }^{13} \mathrm{C}\left\{{ }^{1} \mathrm{H}\right\}$ NMR spectrum is assigned as the $\mathrm{Rh}-\mathrm{C}_{\text {carbene }}$ resonance, indicating the success of carbene transfer from Ag to Rh. The methylene linker between imidazole and pyridine rings exhibited two sets of doublet at 6.39 and 5.92 with the coupling constant of $14.8 \mathrm{~Hz}$, showing two non-equivalent natures of these protons. In addition the ortho-positioned methyl groups on the phenyl ring are magnetically non-equivalent, resulting from the hindered rotation of the methylene unit caused by the bulky substituents and ligands.

ORTEP plot of $\mathbf{6}$ is shown in Fig. 2. Molecular geometry around the metal ion was in square planar arrangement with two coordination sites occupied by carbene and chloride. It is quite clear that the pyridinyl nitrogen donor remains uncoordinated. The average distances of $\mathrm{Rh}-$ $\mathrm{C}_{(\mathrm{COD})}$ trans to carbene donor $[2.18 \AA]$ appears to be longer than those in cis arrangement [2.10 $\mathrm{A}]$, suggesting that the $\sigma$-donor character of the diaminocarbene is stronger than that of chloride. No major deviation was observed in bond lengths (Table 1). It is noticed that the imidazol-2ylidene ring is bisected with the coordination plane by ca. $63.6^{\circ}$.

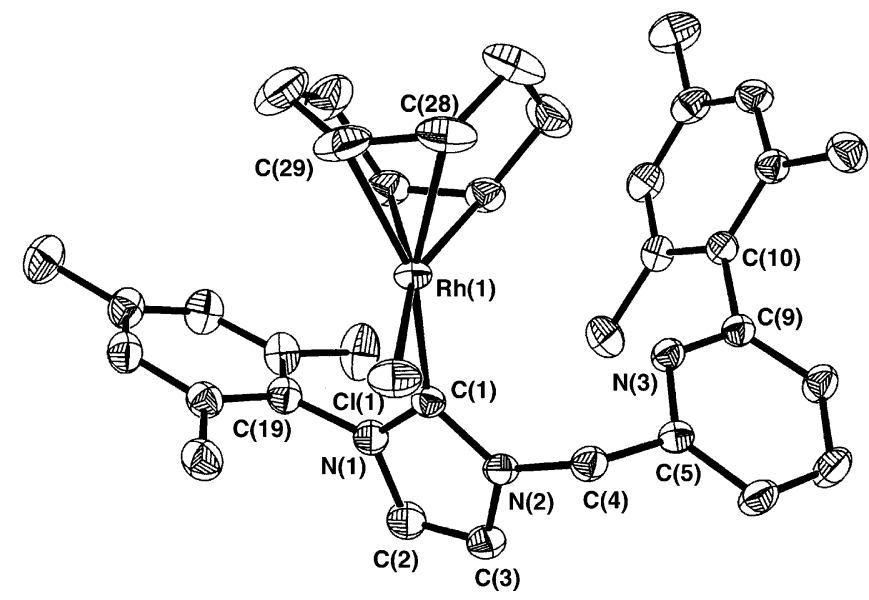

Fig. 2. Molecular structure of rhodium carbene complex 6 (30\% probability ellipsoids).
Table 1

Selected bond lengths $(\AA)$ and bond angles $\left(^{\circ}\right)$

\begin{tabular}{lcccc}
\hline Complex & $\mathbf{6}, \mathrm{X}=\mathrm{Cl}(1)$ & $\mathbf{7}, \mathrm{X}=\mathrm{N}(3)$ & $\mathbf{8}, \mathrm{X}=\mathrm{N}(4)$ & $\mathbf{9}, \mathrm{X}=\mathrm{N}(3)$ \\
\hline $\mathrm{Rh}(1)-\mathrm{C}(1)$ & $2.045(2)$ & $2.044(4)$ & $2.038(3)$ & $2.051(4)$ \\
$\mathrm{Rh}(1)-\mathrm{X}$ & $2.3942(6)$ & $2.223(3)$ & $2.180(3)$ & $2.160(3)$ \\
$\mathrm{C}(1)-\mathrm{N}(1)$ & $1.367(3)$ & $1.371(6)$ & $1.363(3)$ & $1.355(5)$ \\
$\mathrm{C}(1)-\mathrm{N}(2)$ & $1.358(3)$ & $1.33(6)$ & $1.357(3)$ & $1.351(5)$ \\
$\mathrm{Rh}(1)-\mathrm{C}(28)$ & $2.185(3)$ & $2.202(4)$ & $2.178(3)$ & $1.919(5)$ \\
$\mathrm{Rh}(1)-\mathrm{C}(29)$ & $2.172(3)$ & $2.241(4)$ & $2.198(3)$ & $1.828(5)$ \\
$\mathrm{Rh}(1)-\mathrm{C}(1)-\mathrm{N}(1)$ & $130.0(2)$ & $141.0(3)$ & $131.4(2)$ & $137.1(3)$ \\
$\mathrm{Rh}(1)-\mathrm{C}(1)-\mathrm{N}(2)$ & $126.5(2)$ & $115.6(3)$ & $125.1(2)$ & $118.4(3)$ \\
$\mathrm{C}(1)-\mathrm{Rh}(1)-\mathrm{N}(3)$ & - & $84.5(1)$ & - & $87.2(1)$ \\
$\mathrm{C}(1)-\mathrm{Rh}(1)-\mathrm{X}$ & $90.75(6)$ & - & $90.8(1)$ & - \\
\hline
\end{tabular}

Abstraction of chloride from complex 6 via the addition of silver ion readily assisted the coordination of pyridinylnitrogen to the rhodium center, allowing the $\mathrm{pyN}^{\wedge} \mathrm{C}$ to form a chelation (Scheme 2). ${ }^{1} \mathrm{H}$ NMR signals corresponding to pyridinyl hydrogens of 7 shifted downfield by ca. $0.4 \mathrm{ppm}$. This coordination chemical shift gave an indication of the coordination of pyridinyl- $N$ donor toward metal center. However, the conclusive confirmation came from X-ray single crystal determination (Fig. 3). Similar to those rhodium complexes, the metal center in 7 again displays a square planar geometry. Bond length of $\mathrm{Rh}-\mathrm{N}[2.223(3) \AA]$ is in the normal range. Notable feature of this structure is a difference of $25^{\circ}$ between the angle of $\mathrm{Rh}(1)-\mathrm{C}(9)-\mathrm{N}(1)$ $\left[141.0(3)^{\circ}\right]$ and $\mathrm{Rh}(1)-\mathrm{C}(9)-\mathrm{N}(2)\left[115.6(3)^{\circ}\right]$, presumably due to the constrain raised from the chelation of $\mathrm{PyN}^{\wedge} \mathrm{C}$. The bisect angle of imidazole ring and rhodium coordination plane is $49.9^{\circ}$, which is smaller than that in $\mathbf{6}$.

\subsection{Reactivity of rhodium complexes}

In order to understand the nature of the pyridinyl carbene bidentate, substitution reactions at the rhodium center with various ligands including $\sigma$-donor and $\pi$-acceptor ligands were examined.

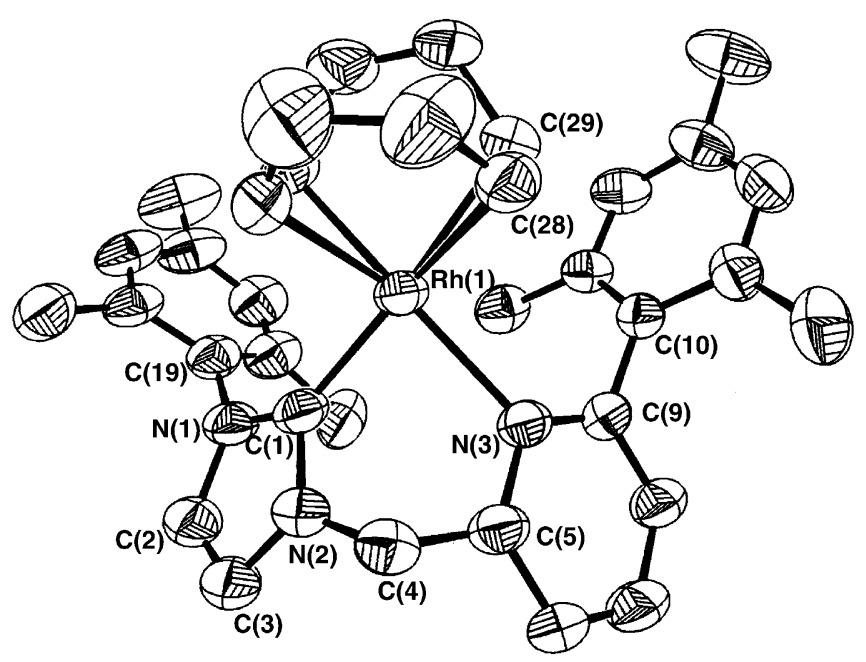

Fig. 3. ORTEP drawing of cationic part of complex 7 (30\% probability ellipsoids). 


\subsubsection{Azide}

While complex 6 reacted with excess amount of sodium azide in refluxing $\mathrm{EtOH} / \mathrm{H}_{2} \mathrm{O}$, chloride was replaced by azide anion to form complex 8 (Scheme 3). Similarly, reaction of 7 with equimolar amount of sodium azide in dichloromethane yielded complex 8 as well. ${ }^{1} \mathrm{H}$ NMR of this resulting complex was quite similar to that of $\mathbf{6}$. Infrared spectrum of the complex showed a characteristic absorption at $2038 \mathrm{~cm}^{-1}$, which is typical for the coordinating azido ligand. Still, the molecular structure of this azide complex was unambiguously proved by X-ray single crystal analysis (Fig. 4). Complex $\mathbf{8}$ appears to be in square-planar coordination geometry around the metal center with all bond angles and lengths in typical ranges. Bond length of $\mathrm{Rh}(1)-\mathrm{C}(9)[2.038(3) \AA]$ was slightly shorter than that of complex 6. As for the bond lengths of $\mathrm{N}-\mathrm{N}$ of the azido ligand are in a difference of about $0.15 \AA$, which is quite different from those reported terminal azido rhodium complexes [16].

This azido rhodium complex proves to be thermally stable and insensitive toward moisture and air. It even remains intact by UV irradiation $(254 \mathrm{~nm})$ at $60{ }^{\circ} \mathrm{C}$ for $12 \mathrm{~h}$. However, the azido moiety readily underwent the ligand transfer from rhodium center to the other metal ion when complex 8 was treated with a THF solution of $[(\mathrm{COD}) \mathrm{RhCl}]_{2}$ or $\left[\mathrm{RuCl}_{2}(p \text {-cymene })\right]_{2}$. In both instances,

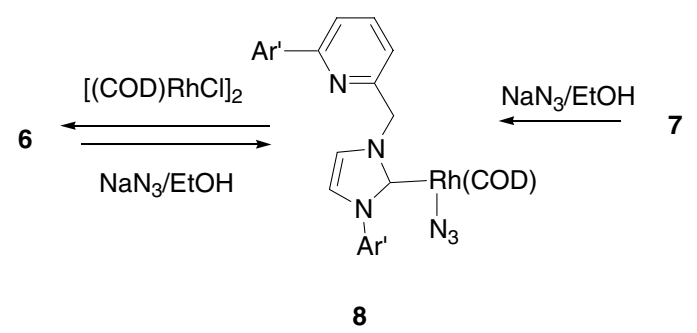

Scheme 3. Activity of rhodium azido complexes.

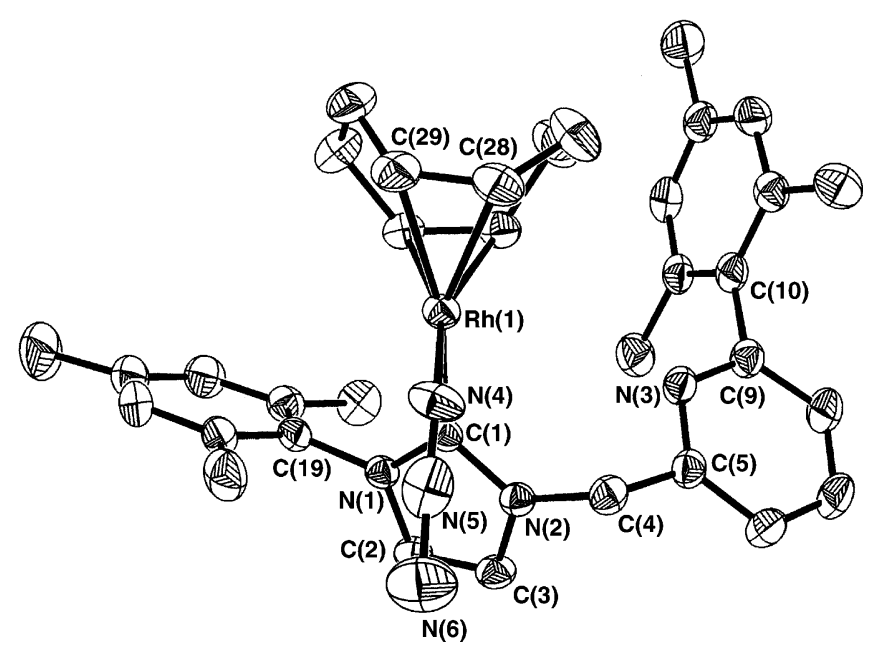

Fig. 4. Molecular structure of rhodium azide complex 8 (30\% probability ellipsoids). the chloro-rhodium 6 was obtained accompanied with the formation of $\left[(\mathrm{COD}) \mathrm{Rh}\left(\mu-\mathrm{N}_{3}\right)\right]_{2}$ or $\left[\mathrm{RuCl}\left(\mu-\mathrm{N}_{3}\right)(p\right.$-cymene) $]_{2}$, respectively. The replacement of the pyridinyl-nitrogen by azide shows the hemi-labile nature this donor, which is also found in the treatment of complex 7 with chloride. Thus, reaction of 7 with excess of tetraethylammonium chloride yielded complex $\mathbf{6}$ quantitatively.

\subsubsection{Carbon monoxide}

Unlike the azide, the coordinating COD of 7 was easily replaced by carbon monoxide [17]. Under the atmospheric pressure of $\mathrm{CO}$, a stirring solution of 7 gave the desired carbonyl substituted rhodium complex 9 quantitatively (Scheme 4). IR spectrum of this complex showed two carbonyl stretching at 2084 and $2031 \mathrm{~cm}^{-1}$, characteristics for rhodium dicarbonyl moiety. The coordination of the strong $\pi$-acid ligands toward metal center causes the downfield shift of protons on both pyridine and imidazole rings in the ${ }^{1} \mathrm{H}$ NMR spectrum. A broad signal between 6.20 and $5.20 \mathrm{ppm}$, with the integration of two protons, was assigned to be the benzylic ones, which is due to the rapid conformation flip of the chelating ring. By lowering the temperature, two sets of doublets was observed, which allowed us to determine the $\Delta G^{\neq}=54.3 \mathrm{~kJ} / \mathrm{mol}$ for the process. The coordinated carbene ligand of 9 manifests a pair of doublet at 172.0 in ${ }^{13} \mathrm{C}\left\{{ }^{1} \mathrm{H}\right\}$ NMR spectrum with rhodium-carbon coupling of $44.9 \mathrm{~Hz}$, which is upfield shift by ca. $2 \mathrm{ppm}$ as compared to that of 7 . Furthermore, X-ray single crystal diffraction was determined to confirm the structure.

ORTEP diagram of 9 is represented in Fig. 5, and selected bond distances and bond angles can be found in Table 1. As expected, the geometry around the rhodium center is square planar, with the chelating $\operatorname{pyN}^{\wedge} \mathrm{C}$ [bite angle $87.2(1)^{\circ}$ ] and two carbonyl ligands. The chelating ring is adopted in a boat conformation, which allows the two methylene protons in different environments. This is in agreement with the spectroscopic analysis. The bond lengths of $\mathrm{Rh}-\mathrm{C}_{\text {(carbene) }}$ [2.051(4) $\AA$ ] and $\mathrm{Rh}-\mathrm{C}_{\text {(carbonyl) }}$ [1.828(5) and 1.919(5) $\mathrm{A}]$ lie in the normal range. The $\mathrm{Rh}-\mathrm{C}_{\text {(carbonyl) }}$ trans to the carbene moiety appears to be

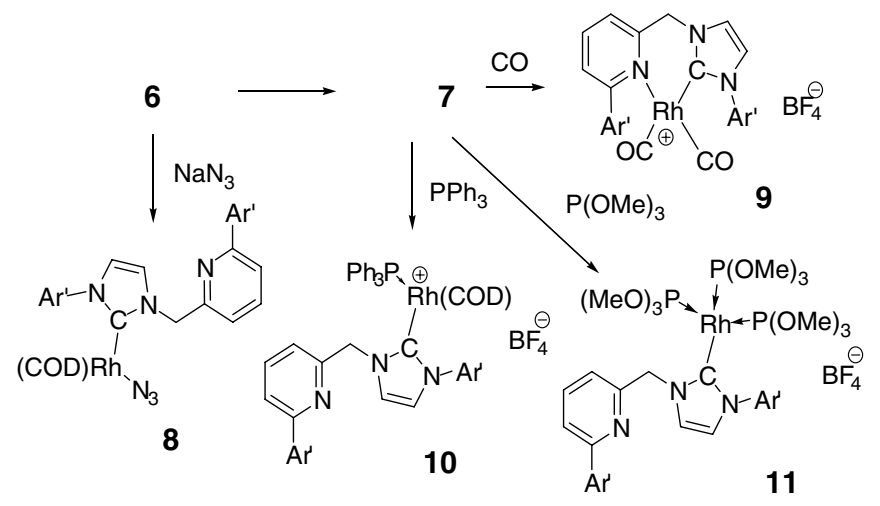

Scheme 4. Ligand substitution reaction with rhodium carbene complexes. 


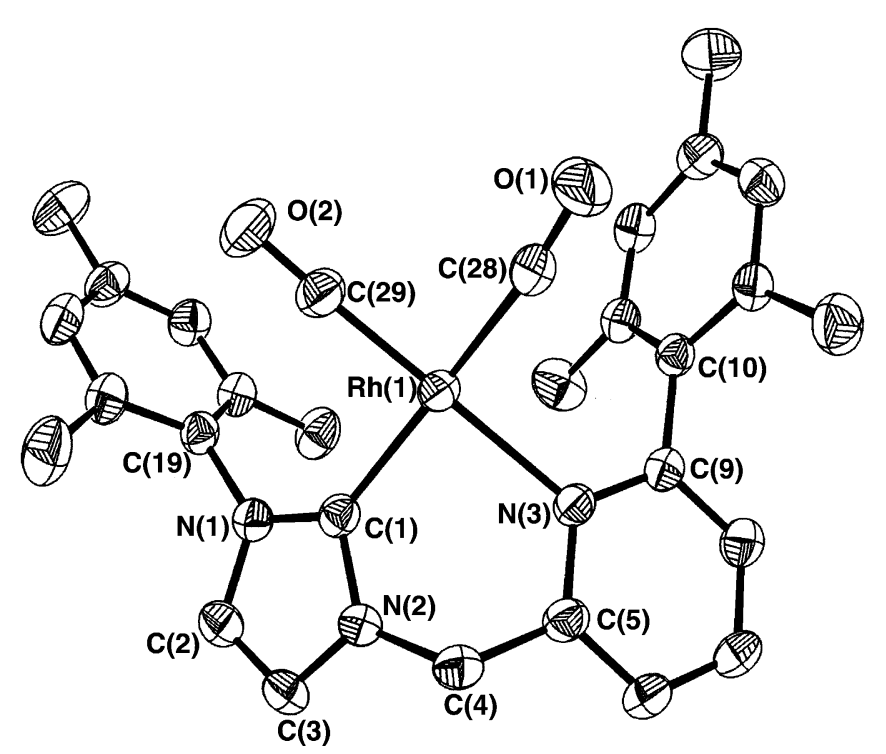

Fig. 5. ORTEP diagram of cationic part of complex $9(30 \%$ probability ellipsoids).

longer than that of cis by about $0.1 \AA$, as anticipated, due to the trans influence. Dihedral angles between rhodium coordination plane and mesityl rings are $62.58^{\circ}$ and $80.45^{\circ}$, showing that these two aromatic rings are bisected with the coordination plane. These two aryl rings along with ortho methyl groups make these two carbonyl ligands adopting into a packet, which causes the angle $\mathrm{Rh}(1)$ $\mathrm{C}(29)-\mathrm{O}(2)\left[171.2(4)^{\circ}\right]$ deviated from $180^{\circ}$ for a relief of the steric interaction.

The chelation as well as the protection of bulky substituents of the carbene ligand $\left(\mathrm{pyN}^{\wedge} \mathrm{C}\right)$ around the metal center renders this carbonyl complex fairly stable. The complex does not show any decomposition in air for weeks. Even the treatment of some strong oxidizing agents such as $\mathrm{H}_{2} \mathrm{O}_{2}$, complex 9 stays intact as evidenced by its spectroscopic analysis.

\subsubsection{Phosphine and phosphite}

Treatment of complex 7 with molar equivalent amount of triphenylphosphine led to the dissociation of the pyridinyl nitrogen with the formation of a cationic phosphinesubstituted rhodium carbene complex 10 (Scheme 4). The resulting complex 10 showed a sharp doublet with $J_{\mathrm{Rh}-\mathrm{P}}=$
$153.5 \mathrm{~Hz}$ in the ${ }^{31} \mathrm{P}\left\{{ }^{1} \mathrm{H}\right\}$ NMR spectrum and a set of doublet of doublet at $\delta 177.5$ with $J_{\mathrm{Rh}-\mathrm{C}}=50.9 \mathrm{~Hz}, J_{\mathrm{P}-\mathrm{C}}=$ $12.1 \mathrm{~Hz}$ for carbene-carbon in ${ }^{13} \mathrm{C}\left\{{ }^{1} \mathrm{H}\right\}$ NMR spectrum, indicating the coordination of phosphine to the metal center. Addition of excess triphenylphosphine did not proceed a further substitution on the metal center. This observation clearly illustrates that the coordination ability of triphenylphosphine, a monodentate, is stronger than that of the chelating pyridinyl nitrogen, but weaker than that of a diaminocarbene donor. The steric bulkiness around metal center also influences the ligand substitution. For example, complex 7 does not proceed the reaction with tri-tert-butylphosphine in chloroform even under refluxing conditions.

Unlike complex 7, this phosphine substituted rhodium complex 10 became air sensitive and was slowly oxidized to yield phosphine-oxide and the chelation complex 7. Presumably, the de-complexation of pyrininyl nitrogen donor readily opens up the "packet", allowing that the ligands on the rhodium center are labile. Thus, the dissociation of phosphine-oxide provided the chelation of $\mathrm{pyN}^{\wedge} \mathrm{C}$ and yield the complex 7 again.

Treatment complex 7 with 3 equiv. of $\mathrm{P}\left(\mathrm{OCH}_{3}\right)_{3}$ resulted in the formation of tris(trimethylphosphite)rhodium complex 11. Apparently, pyridinyl-nitrogen and COD were all substituted by phosphite ligands, a $\pi$-acid donor. This new tris(phosphite)rhodium carbene complex showed two sets of signals in ${ }^{31} \mathrm{P}\left\{{ }^{1} \mathrm{H}\right\}$ NMR spectrum: one of which showing doublet of doublet at 130.9 with $J_{\mathrm{Rh}-\mathrm{P}}$ $=222.2 \mathrm{~Hz}$ and $J_{\mathrm{P}-\mathrm{P}}=70.0 \mathrm{~Hz}$ was assigned to the two phosphites in trans relationship; the other one in triplet of doublet at 138.5 with $J_{\mathrm{Rh}-\mathrm{P}}=191.7 \mathrm{~Hz}, J_{\mathrm{P}-\mathrm{P}}=70.0 \mathrm{~Hz}$ was due to the phosphite trans to the carbene ligand. Observation of $\mathrm{m} / \mathrm{z}=870.2280$ on the HR-FAB mass spectrum, consistent with the formula of $\mathrm{C}_{36} \mathrm{H}_{56} \mathrm{~N}_{3} \mathrm{O}_{9} \mathrm{P}_{3}{ }^{103} \mathrm{Rh}$, clearly illustrated the existence of complex 11.

In contrast to monophosphine, both $\mathrm{COD}$ and $\mathrm{pyN}^{\wedge} \mathrm{C}$ ligands of complex 7 were completely substituted by bisphosphine ligands such as dppe [1,2-bis(diphenylphosphino)-ethane] or dppp [1,3-bis(diphenylphosphino)propane]. Thus reaction of 7 with two equimolar amount of bisphosphine gave $\left[(\text { bisphosphine })_{2} \mathrm{Rh}\right]^{+}$species (Scheme 5). The resulting bisphosphine complexes was subsequently oxidized with molecular oxygen to form $[\mathrm{Rh}$ (bisphosphine $\left.)_{2}\left(\mathrm{O}_{2}\right)\right]^{+}$species $[18,19]$.

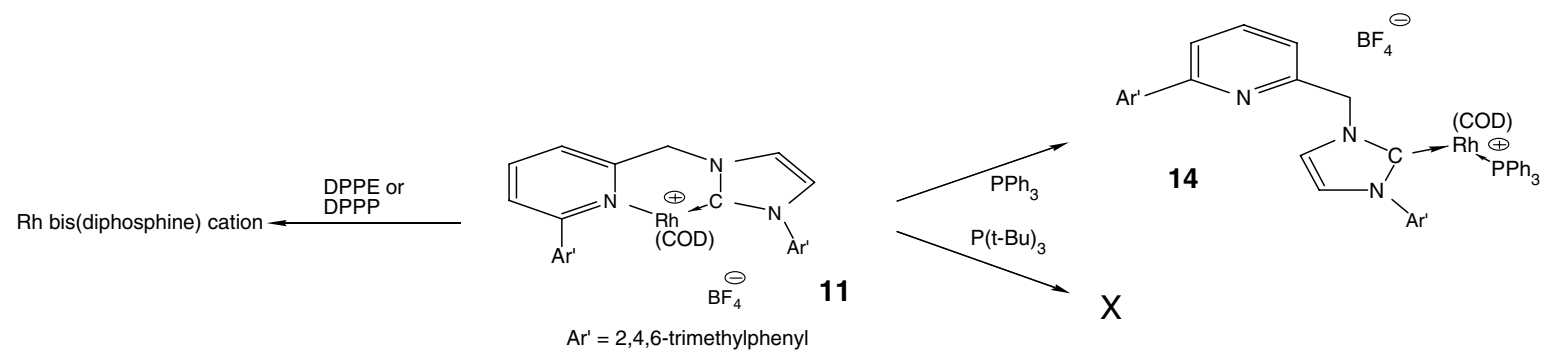

Scheme 5. Replacement of carbene ligand by bisphosphine. 


\section{Summary}

The synthetically easily accessible rhodium carbene complex $\mathbf{6}$ is a good precursor for further coordination study. Considering the results of this study, it is obvious that the pyridinyl-nitrogen donor is labile in the rhodium complexes particularly in the presence of other $\sigma$-donors. With $\pi$-acceptor ligands, this bidentate shows its chelation effect and steric hindrance on stabilization of the complex itself. However, the diaminocarbene ligand can be easily replaced by a bisphosphine, suggesting a favorable chelation effect of phosphine toward rhodium(I) ion center.

\section{Experimental}

\subsection{General}

All reactions and manipulations were performed under a dry nitrogen atmosphere unless otherwise noted. Tetrahydrofuran was distilled under nitrogen from sodium benzophenone ketyl. Dichloromethane was dried over $\mathrm{CaH}_{2}$ and distilled under nitrogen. Other solvents were degassed before use. Chemicals were purchased from commercial source and used without further purification.

Nuclear magnetic resonance spectra were recorded in $\mathrm{CDCl}_{3}$ or acetone- $d_{6}$ on either a Bruker AM-300 or AVANCE 400 spectrometer. Chemical shifts are given in parts per million relative to $\mathrm{Me}_{4} \mathrm{Si}$ for ${ }^{1} \mathrm{H}$ and ${ }^{13} \mathrm{C}\left\{{ }^{1} \mathrm{H}\right\}$ NMR, and relative to $85 \% \mathrm{H}_{3} \mathrm{PO}_{4}$ for ${ }^{31} \mathrm{P}$ NMR. Infrared spectra were measured on a Nicolet Magna-IR 550 spectrometer (Series-II) as $\mathrm{KBr}$ pallets, unless otherwise noted.

\subsection{Synthesis and characterization}

\subsubsection{6-Mesityl-pyridine-2-carboxaldehyde (4)}

To a solution of 6-bromopyridine-2-carboxaldehyde $(1.00 \mathrm{~g}, \quad 5.38 \mathrm{mmol})$, mesitylboronic acid $(1.34 \mathrm{~g}, 8.17$ $\mathrm{mmol})$ and $\mathrm{Pd}\left(\mathrm{PPh}_{3}\right)_{4}(0.25 \mathrm{~g}, 0.22 \mathrm{mmol}, 5 \mathrm{~mol} \%)$ in toluene $(34 \mathrm{ml})$ and methanol $(8.5 \mathrm{ml})$ under nitrogen was added an aqueous sodium carbonate solution (2 M, $17.5 \mathrm{ml})$. The resulting mixture was heated to reflux for $16 \mathrm{~h}$. Upon cooling, the organic layer was collected and the water layer was extracted with ethyl acetate $(50 \mathrm{~mL}$ $\times 2$ ). All organic extracts were combined and dried with $\mathrm{MgSO}_{4}$. After the concentration, the residue was chromatographed on silica gel with elution of ethyl acetate/ hexane $=1 / 20\left(R_{\mathrm{f}}=0.6\right)$ to give the desired product 4 as white solids $(1.09 \mathrm{~g}, 90 \%):{ }^{1} \mathrm{H}$ NMR $(400 \mathrm{MHz}$, $\left.\mathrm{CDCl}_{3}\right) \delta 10.09(\mathrm{~s}, 1 \mathrm{H}), 7.92(\mathrm{~m}, 1 \mathrm{H}), 7.47-7.43(\mathrm{~m}$, $2 \mathrm{H}), 6.92(\mathrm{~s}, 2 \mathrm{H}), 2.32(\mathrm{~s}, 3 \mathrm{H}), 2.01(\mathrm{~s}, 6 \mathrm{H}),{ }^{13} \mathrm{C}\left\{{ }^{1} \mathrm{H}\right\}$ NMR $\left(100 \mathrm{MHz}, \mathrm{CDCl}_{3}\right) \delta 193.7,160.6,152.6,138.0$, $137.2,136.3,135.5,129.0,128.4,119.3,21.2,20.3$. IR $\left(\mathrm{KBr}, \mathrm{cm}^{-1}\right): 3072(\mathrm{w}), 2933(\mathrm{~s}), 2853$ (s), $2740(\mathrm{w})$, 2687 (w), 1706 (vs), 1600 (s), 1454 (s). Anal. Calc. for $\mathrm{C}_{15} \mathrm{H}_{15} \mathrm{NO}$ : C, 79.97; H, 6.71; N, 6.22. Found: C, 80.08; $\mathrm{H}, 6.88 ; \mathrm{N}, 5.96 \%$.
4.2.2. 1-(6-Mesityl-2-picolyl)-3-mesitylimidazolium bromide (3)

To a solution of $4(1.09 \mathrm{~g}, 4.85 \mathrm{mmol})$ in methanol $(10 \mathrm{ml})$ was added into the $\mathrm{NaBH}_{4}(0.28 \mathrm{~g}, 7.27 \mathrm{mmol})$ in methanol $(10 \mathrm{ml})$ at $0{ }^{\circ} \mathrm{C}$. The resulting solution was then heated to reflux for $1 \mathrm{~h}$. Upon evaporation of $\mathrm{MeOH}$, 2hydroxymethyl-6-mesityl-pyridine was obtained as white solids by the addition of water $(10 \mathrm{ml})$ to the residue. Without further purification, this alcohol was used for the following transformation. $\mathrm{PBr}_{3}(0.7 \mathrm{ml}, 7.45 \mathrm{mmol})$ was added to a solution of 2-hydroxymethyl-6-mesityl-pyridine $(0.65 \mathrm{~g}, 2.86 \mathrm{mmol})$ in $\mathrm{CH}_{2} \mathrm{Cl}_{2}(13 \mathrm{ml})$ at $0{ }^{\circ} \mathrm{C}$. The mixture was stirred at room temperature overnight and then treated with water $(10 \mathrm{~mL})$. Upon neutralization, the reaction mixture was washed with saturated sodium bicarbonate aqueous solution and the organic portion was separated. The organic layer was collected and dried with $\mathrm{MgSO}_{4}$. Upon concentration, the desired bromide was collected and used for the following step. A mixture of 2-bromomethyl-6mesitylpyridine and 1-mesitylimidazole $(0.54 \mathrm{~g}, 2.90 \mathrm{mmol})$ in THF ( $20 \mathrm{ml})$ was then added. The resulting mixture was heated to reflux overnight. During the reaction, white solids gradually precipitated, which was collected by filtration $(1.30 \mathrm{~g}, 95 \%):{ }^{1} \mathrm{H}$ NMR $\left(400 \mathrm{MHz}, \mathrm{CDCl}_{3}\right) \delta 10.23(\mathrm{~s}, 1 \mathrm{H})$, $8.00(\mathrm{~s}, 1 \mathrm{H}), 7.96(\mathrm{~d}, 1 \mathrm{H}, J=7.2 \mathrm{~Hz}), 7.81(\mathrm{dd}, 1 \mathrm{H}$, $J=7.2 \mathrm{~Hz}, 7.2 \mathrm{~Hz}), 7.18(\mathrm{~d}, 1 \mathrm{H}, J=7.2 \mathrm{~Hz}), 7.03(\mathrm{~s}$, $1 \mathrm{H}), 6.94(\mathrm{~s}, 2 \mathrm{H}), 6.89$ (s, 2H), 6.19 (s, 2H), 2.30 (s, 6H), $1.94(\mathrm{~s}, 6 \mathrm{H}), 1.89(\mathrm{~s}, 6 \mathrm{H}) .{ }^{13} \mathrm{C}\left\{{ }^{1} \mathrm{H}\right\}$ NMR $(100 \mathrm{MHz}) \delta$ $159.6,152.0,140.8,137.7,137.5,137.3,136.7,135.0$, $133.9,130.3,129.4,127.9,124.5,123.6,122.2,121.4,53.8$, 21.0, 20.1, 17.3. Anal. Calc. for $\mathrm{C}_{27} \mathrm{H}_{30} \mathrm{~N}_{3} \mathrm{Br}$ : C, 68.06; $\mathrm{H}$, 6.35 ; N, 8.82. Found: C, 68.13; H, 6.03; N, 8.88\%.

\subsubsection{Silver carbene complex (5)}

To a solution of $6(0.73 \mathrm{~g}, 1.53 \mathrm{mmol})$, silver oxide $(0.18 \mathrm{~g}, 0.78 \mathrm{mmol})$ and sodium iodide $(0.24 \mathrm{~g}, 1.60 \mathrm{mmol})$ in $\mathrm{CH}_{2} \mathrm{Cl}_{2}(20 \mathrm{ml})$ were stirred at room temperature for $48 \mathrm{~h}$. Filtration of the reaction mixture through Celite gave a colorless solution, which was then concentrated. Upon the addition of hexane to the crude reaction mixture, complex 5 was precipitated and isolated as white solids $(0.92 \mathrm{~g}$, 95\%). ${ }^{1} \mathrm{H}$ NMR $\left(400 \mathrm{MHz}, \mathrm{CDCl}_{3}\right) \delta 7.74(\mathrm{dd}, 1 \mathrm{H}$, $J=8.0 \mathrm{~Hz}, 8.0 \mathrm{~Hz}), 7.45(\mathrm{~d}, 1 \mathrm{H}, J=8.0 \mathrm{~Hz}), 7.36(\mathrm{~d}, 1 \mathrm{H}$, $J=1.6 \mathrm{~Hz}), 7.16(\mathrm{~d}, 1 \mathrm{H}, J=8.0 \mathrm{~Hz}), 6.91(\mathrm{~s}, 2 \mathrm{H}), 6.88$ $(\mathrm{s}, 2 \mathrm{H}), 6.84(\mathrm{~d}, 1 \mathrm{H}, J=1.6 \mathrm{~Hz}), 5.51(\mathrm{~s}, 2 \mathrm{H}), 2.30(\mathrm{~s}$, $6 \mathrm{H}), \quad 1.94(\mathrm{~s}, \quad 6 \mathrm{H}), \quad 1.86 \quad(\mathrm{~s}, \quad 6 \mathrm{H}) .{ }^{13} \mathrm{C}\left\{{ }^{1} \mathrm{H}\right\} \quad \mathrm{NMR}$ $(100 \mathrm{MHz}) \delta 183.5(\mathrm{Ag}=\mathrm{C}), 159.4,154.9,138.5,137.6$, $137.2,137.1,135.3,135.2,134.6,128.8,128.1,124.0$, $122.1,122.0,121.2,57.0,21.2,21.1,20.3,17.8$. HRFABMS for $\left[\mathrm{M}^{+}\right]$: Calc. $897.3774\left(\mathrm{C}_{54} \mathrm{H}_{58} \mathrm{~N}_{6}{ }^{107} \mathrm{Ag}\right)$ : Found: 897.3765. Anal. Calc. for $\mathrm{C}_{54} \mathrm{H}_{58} \mathrm{~N}_{6} \mathrm{Ag}_{2} \mathrm{I}_{2}$ : C, 51.45; H, 4.64; N, 6.67. Found: C, 51.28; H, 4.44; N, 6.60\%.

\subsection{4. $\left(C-p y N^{\wedge} C\right) R h(C O D) C l(6)$}

A mixture of silver complex $5(630 \mathrm{mg}, 0.98 \mathrm{mmol})$ and $[\mathrm{RhCl}(\mathrm{COD})]_{2}(242 \mathrm{mg}, 0.49 \mathrm{mmol})$ in dichloromethane $(25 \mathrm{ml})$ was stirred at room temperature for $3 \mathrm{~h}$. The 
resulting solution was filtrated through Celite followed by concentration and crystallization from $\mathrm{CH}_{2} \mathrm{Cl}_{2}$ /hexane to afford yellow crystalline solids $(635 \mathrm{mg}, 99 \%):{ }^{1} \mathrm{H}$ NMR $\left(400 \mathrm{MHz}, \mathrm{CDCl}_{3}\right) \delta 7.79(\mathrm{dd}, 1 \mathrm{H}, J=7.2 \mathrm{~Hz}, 7.2 \mathrm{~Hz})$, $7.69(\mathrm{~d}, 1 \mathrm{H}, J=7.2 \mathrm{~Hz}), 7.17(\mathrm{~d}, 1 \mathrm{H}, J=7.2 \mathrm{~Hz}), 7.11$ $(\mathrm{d}, 1 \mathrm{H}, J=1.6 \mathrm{~Hz}), 7.08(\mathrm{~s}, 1 \mathrm{H}), 6.91(\mathrm{~s}, 2 \mathrm{H}), 6.88(\mathrm{~s}$, $1 \mathrm{H}), 6.70(\mathrm{~d}, 1 \mathrm{H}, J=1.6 \mathrm{~Hz}), 6.39(\mathrm{~d}, 1 \mathrm{H}, J=14.8 \mathrm{~Hz})$, $5.92(\mathrm{~d}, 1 \mathrm{H}, J=14.8 \mathrm{~Hz}), 4.91-4.78(\mathrm{~m}, 2 \mathrm{H}), 3.27(\mathrm{~m}$, $1 \mathrm{H}), 2.93(\mathrm{~m}, 1 \mathrm{H}), 2.45(\mathrm{~s}, 3 \mathrm{H}), 2.36(\mathrm{~s}, 3 \mathrm{H}), 2.31(\mathrm{~s}$, $3 \mathrm{H}), 2.24-2.10(\mathrm{~m}, 2 \mathrm{H}), 2.03-1.94(\mathrm{~m}, 1 \mathrm{H}), 1.98(\mathrm{~s}, 6 \mathrm{H})$, $1.75(\mathrm{~s}, 3 \mathrm{H}), 1.73-1.64(\mathrm{~m}, 3 \mathrm{H}), 1.49-1.42(\mathrm{~m}, 2 \mathrm{H})$. ${ }^{13} \mathrm{C}\left\{{ }^{1} \mathrm{H}\right\} \quad$ NMR $(100 \mathrm{MHz}) \delta 182.0\left(\mathrm{~d}, J_{\mathrm{Rh}-\mathrm{C}}=51 \mathrm{~Hz}\right)$, $159.1,155.8,138.0,137.0,136.6,135.7,135.1,133.9$, $129.1,127.9,127.7,123.5,122.6,121.4,120.9,97.0(\mathrm{~d}$, $\left.J_{\mathrm{Rh}-\mathrm{C}}=6.9 \mathrm{~Hz}\right), 96.9\left(\mathrm{~d}, J_{\mathrm{Rh}-\mathrm{C}}=7.6 \mathrm{~Hz}\right), 68.8\left(\mathrm{~d}, J_{\mathrm{Rh}-\mathrm{C}}\right.$ $=14.5 \mathrm{~Hz}), 67.5\left(\mathrm{~d}, J_{\mathrm{Rh}-\mathrm{C}}=14.4 \mathrm{~Hz}\right), 56.8,34.1,31.8$, $29.4,28.3,21.4,20.6,20.1,18.0$. HR-FAB for $[\mathrm{M}-\mathrm{Cl}]^{+}$: Calc. $606.2355\left(\mathrm{C}_{35} \mathrm{H}_{41} \mathrm{~N}_{3}{ }^{103} \mathrm{Rh}\right.$ ), Found: 606.2357. Anal. Calc. for $\mathrm{C}_{35} \mathrm{H}_{41} \mathrm{~N}_{3} \mathrm{ClRh}: \mathrm{C}, 65.47 ; \mathrm{H}, 6.44 ; \mathrm{N}, 6.54$. Found: C, 65.21; H, 6.69; N, 6.28\%.

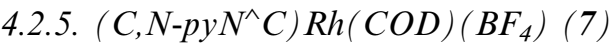

A mixture of complex $6(221.3 \mathrm{mg}, 0.35 \mathrm{mmol})$ and silver tetrafluoroborate $(70.0 \mathrm{mg}, 0.36 \mathrm{mmol})$ in $\mathrm{CH}_{2} \mathrm{Cl}_{2}(30 \mathrm{ml})$ was stirred under nitrogen at the ambient temperature for $1 \mathrm{~h}$. The mixture was filtrated through Celite and the filtrate was collected and concentrated. Recrystallization from a solution of $\mathrm{CH}_{2} \mathrm{Cl}_{2}$ and hexane provided the desired product as yellow crystalline solids, which were suitable for Xray single crystal diffraction analysis. (230.1 mg, 96\%): ${ }^{1} \mathrm{H}$ NMR $\left(400 \mathrm{MHz}, \mathrm{CDCl}_{3}\right) \delta 8.14(\mathrm{dd}, 1 \mathrm{H}, J=7.6 \mathrm{~Hz}$, $1.2 \mathrm{~Hz}), 7.94-7.91(\mathrm{~m}, 2 \mathrm{H}), 7.22(\mathrm{~d}, 1 \mathrm{H}, J=1.6 \mathrm{~Hz}), 7.03$ $(\mathrm{s}, 1 \mathrm{H}), 6.93(\mathrm{~s}, 1 \mathrm{H}), 6.90(\mathrm{~s}, 1 \mathrm{H}), 6.85(\mathrm{~s}, 1 \mathrm{H}), 6.60(\mathrm{~d}, 1 \mathrm{H}$, $J=1.6 \mathrm{~Hz}), 6.38(\mathrm{~d}, 1 \mathrm{H}, J=14.0 \mathrm{~Hz}), 6.17(\mathrm{~d}, 1 \mathrm{H}$, $J=14.0 \mathrm{~Hz}), 4.68-4.64(\mathrm{~m}, 1 \mathrm{H}), 3.81-3.79(\mathrm{~m}, 1 \mathrm{H}), 3.63$ $(\mathrm{m}, 1 \mathrm{H}), 2.66-2.60(\mathrm{~m}, 1 \mathrm{H}), 2.48-2.40(\mathrm{~m}, 1 \mathrm{H}), 2.35(\mathrm{~s}$, $3 \mathrm{H}), 2.33(\mathrm{~s}, 3 \mathrm{H}), 2.31(\mathrm{~s}, 3 \mathrm{H}), 2.06-1.93(\mathrm{~m}, 4 \mathrm{H}), 1.89(\mathrm{~s}$, $3 \mathrm{H}), 1.86(\mathrm{~s}, 3 \mathrm{H}), 1.64(\mathrm{~s}, 3 \mathrm{H}), 1.64(\mathrm{~s}, 3 \mathrm{H}), 1.43-1.39(\mathrm{~m}$, $1 \mathrm{H}), 1.23-1.14(\mathrm{~m}, 2 \mathrm{H}) .{ }^{13} \mathrm{C}\left\{{ }^{1} \mathrm{H}\right\}$ NMR $(100 \mathrm{MHz}) \delta$ $174.2\left(\mathrm{~d}, \quad J_{\mathrm{Rh}-\mathrm{C}}=52.5 \mathrm{~Hz}\right), 161.3,154.7,139.2,139.0$, $137.0,136.1,135.4,134.8,134.5,128.6,128.5,128.1,127.8$, 127.6, 124.3, 123.3, 122.9, $98.2\left(\mathrm{~d}, J_{\mathrm{Rh}-\mathrm{C}}=7.6 \mathrm{~Hz}\right), 94.9$ $\left(\mathrm{d}, J_{\mathrm{Rh}-\mathrm{C}}=6.8 \mathrm{~Hz}\right), 73.5\left(\mathrm{~d}, J_{\mathrm{Rh}-\mathrm{C}}=13.7 \mathrm{~Hz}\right), 71.8(\mathrm{~d}$, $\left.J_{\mathrm{Rh}-\mathrm{C}}=12.2 \mathrm{~Hz}\right), 56.7,35.4,32.0,29.2,26.5,23.4,21.5$, 21.4, 21.1, 18.6, 18.2. Anal. Calc. for $\mathrm{C}_{35} \mathrm{H}_{41} \mathrm{~N}_{3} \mathrm{BF}_{4} \mathrm{Rh}: \mathrm{C}$, $60.62 ; \mathrm{H}, 5.96 ; \mathrm{N}, 6.06$. Found: C, 60.41; H, 6.07; N, 5.95\%.

\subsection{6. $\left(C-p y N^{\wedge} C\right) R h(C O D)\left(N_{3}\right)(8)$}

Complex $6(63.5 \mathrm{mg}, 0.10 \mathrm{mmol})$ and sodium azide $(19.8 \mathrm{mg}, 0.31 \mathrm{mmol})$ was dissolved in ethanol $(10 \mathrm{ml})$ and water $(5 \mathrm{ml})$. The resulting solution was heat to reflux for $6 \mathrm{~h}$ under nitrogen. Removal of ethanol, the residue was extracted with ethyl acetate $(20 \mathrm{ml} \times 3)$. All organic portions were combined and dried over $\mathrm{MgSO}_{4}$. Recrystallization from ethyl acetate and hexane gave the desired complex in yellow solids (50.3 mg, 79\%): ${ }^{1} \mathrm{H}$ NMR $\left(400 \mathrm{MHz}, \mathrm{CDCl}_{3}\right)$ $\delta 7.81(\mathrm{dd}, 1 \mathrm{H}, J=7.6 \mathrm{~Hz}, 7.6 \mathrm{~Hz}), 7.58(\mathrm{~d}, 1 \mathrm{H}, J=$
$7.6 \mathrm{~Hz}), 7.18(\mathrm{~d}, 1 \mathrm{H}, J=7.6 \mathrm{~Hz}), 7.16(\mathrm{~s}, 1 \mathrm{H}), 7.12(\mathrm{~s}$, $1 \mathrm{H}), 6.91(\mathrm{~s}, 2 \mathrm{H}), 6.89(\mathrm{~s}, 1 \mathrm{H}), 6.75(\mathrm{~s}, 1 \mathrm{H}), 6.37(\mathrm{~d}, 1 \mathrm{H}$, $J=15.2 \mathrm{~Hz}), 5.82(\mathrm{~d}, 1 \mathrm{H}, J=15.2 \mathrm{~Hz}), 4.52(\mathrm{~m}, 2 \mathrm{H}), 3.28$ $(\mathrm{m}, 1 \mathrm{H}), 2.82(\mathrm{~m}, 1 \mathrm{H}), 2.46(\mathrm{~s}, 3 \mathrm{H}), 2.37(\mathrm{~s}, 3 \mathrm{H}), 2.32(\mathrm{~s}$, $3 \mathrm{H}), 2.12-2.04(\mathrm{~m}, 3 \mathrm{H}), 1.99(\mathrm{~s}, 6 \mathrm{H}), 1.76(\mathrm{~s}, 3 \mathrm{H}), 1.70$ $1.60(\mathrm{~m}, \quad 3 \mathrm{H}), \quad 1.46-1.44 \quad(\mathrm{~m}, \quad 2 \mathrm{H}) .{ }^{13} \mathrm{C}\left\{{ }^{1} \mathrm{H}\right\} \quad \mathrm{NMR}$ $(100 \mathrm{MHz}) \delta 181.9\left(\mathrm{~d}, J^{\mathrm{Rh}-\mathrm{C}}=52.5 \mathrm{~Hz}\right), 159.3,155.7$, $138.1,137.1,136.9,136.7,135.6,135.1,133.8,129.1$, $128.0,127.8,123.6,122.9,121.7,120.4,95.4\left(\mathrm{~d}, J_{\mathrm{Rh}-\mathrm{C}}=\right.$ $7.6 \mathrm{~Hz}), \quad 94.8\left(\mathrm{~d}, \quad J_{\mathrm{Rh}-\mathrm{C}}=7.6 \mathrm{~Hz}\right), \quad 70.2\left(\mathrm{~d}, \quad J_{\mathrm{Rh}-\mathrm{C}}=\right.$ $12.9 \mathrm{~Hz}), 69.0\left(\mathrm{~d}, J_{\mathrm{Rh}-\mathrm{C}}=13.7 \mathrm{~Hz}\right), 56.1,33.9,31.7,29.6$, 28.6, 21.5, 20.6, 18.4, 18.1. IR ( $\left.\mathrm{KBr}, \mathrm{cm}^{-1}\right): 2038$ (s), 1235 (w). Anal. Calc. for $\mathrm{C}_{35} \mathrm{H}_{41} \mathrm{~N}_{6} \mathrm{Rh}: \mathrm{C}, 64.81 ; \mathrm{H}, 6.37 ; \mathrm{N}$, 12.96. Found: C, 64.66; H, 6.73; N, 12.70\%.

\subsection{7. $\left(\mathrm{C}, \mathrm{N}-\mathrm{py} \mathrm{N}^{\wedge} \mathrm{C}\right) \mathrm{Rh}(\mathrm{CO})_{2}\left(\mathrm{BF} \mathrm{F}_{4}\right)(\mathbf{9})$}

To a solution of complex $7(111.6 \mathrm{mg}, 0.16 \mathrm{mmol})$ in $\mathrm{CH}_{2} \mathrm{Cl}_{2}(30 \mathrm{ml})$ was stirring under $\mathrm{CO}(1 \mathrm{~atm})$ for $3 \mathrm{~h}$ at r.t. After filtrating through Celite, the solution was concentrated and yielded yellow solids. Recrystallization from $\mathrm{CH}_{2} \mathrm{Cl}_{2}$ and hexane provided yellow solids $(95.8 \mathrm{mg}$, 93\%), which are suitable for single crystal X-ray diffraction analysis. ${ }^{1} \mathrm{H}$ NMR $\left(400 \mathrm{MHz}, \mathrm{CDCl}_{3}\right) \delta 8.28(\mathrm{~d}, 1 \mathrm{H}$, $J=8.0 \mathrm{~Hz}), 8.11(\mathrm{dd}, 1 \mathrm{H}, J=8.0 \mathrm{~Hz}, 8.0 \mathrm{~Hz}), 8.06(\mathrm{~d}$, $1 \mathrm{H}, J=2.0 \mathrm{~Hz}), 7.41(\mathrm{~d}, 1 \mathrm{H}, J=8.0 \mathrm{~Hz}), 6.97(\mathrm{~s}, 2 \mathrm{H})$, $6.96(\mathrm{~s}, 2 \mathrm{H}), 6.91(\mathrm{~d}, 1 \mathrm{H}, J=2.0 \mathrm{~Hz}), 6.20-5.20(2 \mathrm{H}, \mathrm{br})$, $2.34(\mathrm{~s}, 6 \mathrm{H}), 1.98(\mathrm{~s}, 6 \mathrm{H}), 1.91(\mathrm{~s}, 6 \mathrm{H}) .{ }^{13} \mathrm{C}\left\{{ }^{1} \mathrm{H}\right\}$ NMR $(100 \mathrm{MHz}) \delta 183.2\left(\mathrm{~d}, J_{\mathrm{Rh}-\mathrm{C}}=70.8 \mathrm{~Hz}\right), 181.6\left(\mathrm{~d}, J_{\mathrm{Rh}-\mathrm{C}}=\right.$ $54.8 \mathrm{~Hz}), 172.0 \quad\left(J_{\mathrm{Rh}-\mathrm{C}}=44.9 \mathrm{~Hz}\right), 163.3,154.4,141.4$, $140.3,140.2,136.6,135.3,134.2,129.2,128.9,128.5,127.7$, 125.7, 124.5, 123.6, 55.1, 31.0, 28.1, 21.3, 21.2, 18.0. IR $\left(\mathrm{KBr}, \mathrm{cm}^{-1}\right): 2933(\mathrm{w}), 2866(\mathrm{w}), 2084(\mathrm{~s}), 2031$ (s), 1620 (m), 1461 (m), 1070 (s). HR-FABMS: Calc. 554.1315 $\left.\left(\mathrm{C}_{29} \mathrm{H}_{29 \mathrm{~N} 3} \mathrm{O}_{2}{ }^{103} \mathrm{Rh}\right),\left[\mathrm{M}^{+}\right]\right), \quad 526.1366\left(\mathrm{C}_{28} \mathrm{H}_{29} \mathrm{~N}_{3} \mathrm{O}^{103} \mathrm{Rh}\right.$, $\left.\left[\mathrm{M}^{+}-\mathrm{CO}\right]\right)$; Found: $554.1305 \quad\left(\mathrm{C}_{29} \mathrm{H}_{29} \mathrm{~N}_{3} \mathrm{O}_{2}{ }^{103} \mathrm{Rh}\right)$, $526.1370\left(\mathrm{C}_{28} \mathrm{H}_{29} \mathrm{~N}_{3} \mathrm{O}^{103} \mathrm{Rh}\right)$. Anal. Calc. for $\mathrm{C}_{29} \mathrm{H}_{29} \mathrm{~N}_{3} \mathrm{O}_{2^{-}}$ $\mathrm{BF}_{4} \mathrm{Rh}$ : C, 54.32; $\mathrm{H}, 4.56$; N, 6.55. Found: $\mathrm{C}, 54.54 ; \mathrm{H}$, $4.85 ; \mathrm{N}, 6.29 \%$.

\subsection{8. $\left[\left(C-p y N^{\wedge} C\right) R h(C O D)\left(P P h_{3}\right)\right] B F_{4}$ (10)}

Complex $7(18.5 \mathrm{mg}, 0.027 \mathrm{mmol})$ and triphenylphosphine $(7.0 \mathrm{mg}, \quad 0.027 \mathrm{mmol})$ dissolved in acetone- $d_{6}$ $(0.4 \mathrm{ml})$ was shaked with sonicator at room temperature for $10 \mathrm{~min}$. NMR spectrum showed the complete conversion into the phosphine-substituted complex. ${ }^{1} \mathrm{H}$ NMR $\left(400 \mathrm{MHz}, \mathrm{CDCl}_{3}\right) \delta 7.96(\mathrm{dd}, 1 \mathrm{H}, J=7.6 \mathrm{~Hz}, 7.6 \mathrm{~Hz})$, 7.62-7.56 (br, 5H), 7.52-7.44 (m, 8H), $7.41(\mathrm{~s}, 1 \mathrm{H}), 7.40$ $(\mathrm{d}, 1 \mathrm{H}, J=7.6 \mathrm{~Hz}), 7.39-7.36(\mathrm{~m}, 3 \mathrm{H}), 7.27(\mathrm{~d}, 1 \mathrm{H}$, $J=7.6 \mathrm{~Hz}), 7.02(\mathrm{~s}, 1 \mathrm{H}), 7.00(\mathrm{~s}, 1 \mathrm{H}), 6.89(\mathrm{~s}, 2 \mathrm{H}), 6.49$ $(\mathrm{d}, 1 \mathrm{H}, \quad J=15.6 \mathrm{~Hz}), 5.42(\mathrm{~m}, 1 \mathrm{H}), 4.71(\mathrm{~d}, 1 \mathrm{H}$, $J=15.6 \mathrm{~Hz}), 4.51(\mathrm{~m}, 1 \mathrm{H}), 4.04(\mathrm{~m}, 1 \mathrm{H}), 3.91(\mathrm{~m}, 1 \mathrm{H})$, $2.37(\mathrm{~s}, 3 \mathrm{H}), 2.29(\mathrm{~s}, 3 \mathrm{H}), 2.00-1.72(\mathrm{~m}, 14 \mathrm{H}), 1.78(\mathrm{~s}$, $3 \mathrm{H}), 1.62(\mathrm{~s}, 3 \mathrm{H}) .{ }^{31} \mathrm{P}\left\{{ }^{1} \mathrm{H}\right\}$ NMR $(161.9 \mathrm{MHz}) \delta 24.1(\mathrm{~d}$, $\left.J_{\mathrm{Rh}-\mathrm{P}}=153.5 \mathrm{~Hz}\right) .{ }^{13} \mathrm{C}\left\{{ }^{1} \mathrm{H}\right\} \quad \mathrm{NMR} \quad(100 \mathrm{MHz}) \delta 177.5$ $\left(\mathrm{dd}, \quad J_{\mathrm{Rh}-\mathrm{C}}=50.6 \mathrm{~Hz}, \quad J_{\mathrm{P}-\mathrm{C}}=11.8 \mathrm{~Hz}\right), \quad 160.0, \quad 155.6$, $139.5,137.7,137.1,136.7,135.9,135.4,134.2,131.9$ (d, $\left.J_{\mathrm{P}-\mathrm{C}}=9.9 \mathrm{~Hz}\right), \quad 131.2, \quad 129.7, \quad 129.2,129.1 \quad\left(\mathrm{~d}, \quad J_{\mathrm{P}-\mathrm{C}}=\right.$ 
$9.1 \mathrm{~Hz}), 128.2,128.1,127.6,124.3\left(\mathrm{~d}, J_{\mathrm{P}-\mathrm{C}}=7.6 \mathrm{~Hz}\right), 120.6$, $97.2\left(\mathrm{dd}, J_{\mathrm{Rh}-\mathrm{C}}=8.4 \mathrm{~Hz}, J_{\mathrm{P}-\mathrm{C}}=8.4 \mathrm{~Hz}\right), 94.2\left(\mathrm{~d}, J_{\mathrm{Rh}-\mathrm{C}}=\right.$ $10.7 \mathrm{~Hz}), 94.1\left(\mathrm{~d}, \quad J_{\mathrm{Rh}_{-} \mathrm{C}}=8.3 \mathrm{~Hz}\right), 91.6\left(\mathrm{~d}, \quad J_{\mathrm{Rh}-\mathrm{C}}=\right.$ $1.6 \mathrm{~Hz}), 56.9,33.2,32.2\left(\mathrm{~d}, J_{\mathrm{Rh}-\mathrm{C}}=3.8 \mathrm{~Hz}\right), 29.2,28.8$, 21.3, 21.1, 20.5, 20.4, 18.0. HR-FABMS for $\left[\mathrm{M}^{+}\right]$: Calc. $868.3267\left(\mathrm{C}_{53} \mathrm{H}_{56} \mathrm{~N}_{3} \mathrm{P}^{103} \mathrm{Rh}\right)$, Found: 868.3278.

\subsection{9. $\left(\mathrm{C}, \mathrm{N}-p y N^{\wedge} \mathrm{C}\right) \mathrm{Rh}\left[\mathrm{P}(\mathrm{OMe})_{3}\right]_{3}\left(\mathrm{BF}_{4}\right)$ (11)}

Trimethylphosphite $(5.7 \mu \mathrm{l}, 0.048 \mathrm{mmol})$ was added into the $\mathrm{CDCl}_{3}$ solution of complex $7(11.0 \mathrm{mg}, 0.016 \mathrm{mmol})$ under nitrogen and mixed with sonication at r.t. Monitoring the reaction by ${ }^{31} \mathrm{P}$ NMR, substitution was completed within 10 min to yield complex 11. ${ }^{1} \mathrm{H}$ NMR $(400 \mathrm{MHz}$, $\left.\mathrm{CDCl}_{3}\right) \delta 7.89(\mathrm{dd}, 1 \mathrm{H}, J=7.6 \mathrm{~Hz}, 7.6 \mathrm{~Hz}, P y), 7.29(\mathrm{~d}$, $1 \mathrm{H}, J=7.6 \mathrm{~Hz}, P y), 7.23(\mathrm{~s}, 1 \mathrm{H}, I m), 7.21(\mathrm{~d}, 1 \mathrm{H}, J=$ $7.6 \mathrm{~Hz}, P y), 6.93(\mathrm{~s}, 3 \mathrm{H}), 6.90(\mathrm{~s}, 2 \mathrm{H}), 3.78-3.67(\mathrm{~m}, 2 \mathrm{H})$, 3.51-3.47 (m, 27H, OMe), 2.30 (s, 3H, Me), 2.27 (s, 3H, $M e), 2.06(\mathrm{~s}, 6 \mathrm{H}, M e), 2.00(\mathrm{~s}, 6 \mathrm{H}, M e) .{ }^{13} \mathrm{C}\left\{{ }^{1} \mathrm{H}\right\}$ NMR $(100 \mathrm{MHz}) \quad \delta \quad 181.9 \quad\left(\mathrm{ddt}, \quad J_{\mathrm{Rh}-\mathrm{C}}=139.5 \mathrm{~Hz}, \quad J_{\mathrm{P}-\mathrm{C}}=\right.$ $43.8 \mathrm{~Hz}, 18.2 \mathrm{~Hz}), 159.2,154.4,138.5,137.1,136.9,136.6$, $135.4,134.8,134.6,128.4,127.9,124.1,124.0,123.6$, $120.8,120.7,120.0,56.9\left(\mathrm{CH}_{2}\right), 52.1,51.8,51.7,21.3$, 21.1, 20.4, 18.2. ${ }^{31} \mathrm{P}\left\{{ }^{1} \mathrm{H}\right\}$ NMR $(121.4 \mathrm{MHz}) \delta 138.5(\mathrm{dt}$, $J_{\mathrm{Rh}-\mathrm{P}}=191.7 \mathrm{~Hz}, \quad J_{\mathrm{P}-\mathrm{P}}=70.0 \mathrm{~Hz}$, trans $\left.\mathrm{P}(\mathrm{OMe})_{3}\right), 130.9$ $\left(\mathrm{dd}, J_{\mathrm{Rh}-\mathrm{P}}=222.2 \mathrm{~Hz}, J_{\mathrm{P}-\mathrm{P}}=70.0 \mathrm{~Hz}, c i s-\mathrm{P}(\mathrm{OMe})_{3}\right)$. HRFABMS for $\left[\mathrm{M}^{+}\right]$: Calc. $870.2284 \quad\left(\mathrm{C}_{36} \mathrm{H}_{56} \mathrm{~N}_{3} \mathrm{O}_{9^{-}}\right.$ $\mathrm{P}_{3}{ }^{103} \mathrm{Rh}$ ), Found: 870.2280.

\subsubsection{0. $\left[(\mathrm{P} \sim \mathrm{P})_{2} \mathrm{Rh}\left(\mathrm{O}_{2}\right)\right] B F_{4}$}

Complex 7 (15.0 mg, $0.021 \mathrm{mmol})$ and diphosphine (17.8 $\mathrm{mg}$ of dppp or $17.2 \mathrm{mg}$ of dppe, $0.043 \mathrm{mmol}$ ) were dissolved in $\mathrm{CDCl}_{3}$ under nitrogen with sonication. The resulting mixture was monitored by ${ }^{31} \mathrm{P}$ NMR spectrum. After the completeness of the replacement, the mixture was exposed to air for $24 \mathrm{~h}$. The obtained complex was purified by extraction and concentration. [(dppp $\left.)_{2} \mathrm{RhBF}_{4}\right]$ : ${ }^{1} \mathrm{H}$ NMR $\left(400 \mathrm{MHz}, \mathrm{CDCl}_{3}\right) \delta 7.21-7.03$ (br, 40H), 2.23$2.12\left(\mathrm{br}, 8 \mathrm{H}, \mathrm{CH}_{2}\right), 1.78$ (br, $\left.4 \mathrm{H}, \mathrm{CH}_{2}\right) .{ }^{31} \mathrm{P}\left\{{ }^{1} \mathrm{H}\right\}$ NMR $\delta$ $8.4\left(\mathrm{~d}, J_{\mathrm{Rh}-\mathrm{P}}=130.8 \mathrm{~Hz}\right) ;\left[(\mathrm{dppp})_{2} \mathrm{Rh}\left(\mathrm{O}_{2}\right) \mathrm{BF}_{4}\right]:{ }^{1} \mathrm{H} \mathrm{NMR}$ $\delta 7.73(\mathrm{br}, 6 \mathrm{H}), 7.38-7.29(\mathrm{~m}, 12 \mathrm{H}), 7.23-7.28(\mathrm{br}, 6 \mathrm{H})$, 7.14-7.10 (m, 4H), $6.98(\mathrm{br}, 6 \mathrm{H}), 6.88-6.83(\mathrm{~m}, 6 \mathrm{H})$, 2.69-2.65 (m, 4H), 2.44-2.29 (br, 8H). ${ }^{31} \mathrm{P}\left\{{ }^{1} \mathrm{H}\right\}$ NMR $\delta$ $15.9\left(\mathrm{dt}, J_{\mathrm{Rh}-\mathrm{P}}=121.5 \mathrm{~Hz}, J_{\mathrm{P}-\mathrm{P}}=30.4 \mathrm{~Hz}\right),-12.2(\mathrm{dt}$, $\left.J_{\mathrm{Rh}-\mathrm{P}}=84.9 \mathrm{~Hz}, \quad J_{\mathrm{P}-\mathrm{P}}=30.4 \mathrm{~Hz}\right) ; \quad\left[(\mathrm{dppe})_{2} \mathrm{RhBF}_{4}\right]:{ }^{1} \mathrm{H}$ NMR $\left(400 \mathrm{MHz}, \mathrm{CDCl}_{3}\right) \delta .36-7.28(\mathrm{~m}, 10 \mathrm{H}), 7.18$ $7.13(\mathrm{~m}, 30 \mathrm{H}), 2.08-2.03$ (br, $8 \mathrm{H}, \mathrm{CH} 2) .{ }^{31} \mathrm{P}$ NMR $\delta$ $58.2\left(\mathrm{~d}, \quad J_{\mathrm{Rh}-\mathrm{P}}=132.7 \mathrm{~Hz}\right) ; \quad\left[(\mathrm{dppe}){ }_{2} \mathrm{Rh}\left(\mathrm{O}_{2}\right) \mathrm{BF}_{4}\right]:{ }^{1} \mathrm{H}$ NMR $\left(\mathrm{CDCl}_{3}\right) \delta 7.61(\mathrm{~m}, 10 \mathrm{H}), 7.43-7.30(\mathrm{~m}, 20 \mathrm{H})$, 7.16-7.14 (m, 10H), 2.49-2.30 (m, 8H, $\left.\mathrm{CH}_{2}\right) .{ }^{31} \mathrm{P}\left\{{ }^{1} \mathrm{H}\right\}$ NMR $\left(\mathrm{CDCl}_{3}, 161.9 \mathrm{MHz}\right): \delta 51.8\left(\mathrm{dt}, \quad J_{\mathrm{Rh}-\mathrm{P}}=125.8\right.$ $\left.\mathrm{Hz}, J_{\mathrm{P}-\mathrm{P}}=8.0 \mathrm{~Hz}\right), 44.5\left(\mathrm{dt}, J_{\mathrm{Rh}-\mathrm{P}}=94.3 \mathrm{~Hz}, J_{\mathrm{P}-\mathrm{P}}=8.0\right.$ $\mathrm{Hz}$ ). These spectral data were consistent with the literature reported data [19].

\subsection{X-ray crystallographic analysis}

Crystals suitable for X-ray determination were obtained for 5-9 by recrystallization at room temperature. Cell parameters were determined either by a Nonius Kappa CCD diffractometer. Crystal data of these complexes are listed in Table 2. All OTEP plots are drawn with 30\% probability ellipsoids and partial labeling for clear view in Figs. $1-5$. Other crystallographic data are deposited as supporting information.

Table 2

Crystallographic data for 5-9

\begin{tabular}{|c|c|c|c|c|c|}
\hline Complex & 5 & 6 & 7 & 8 & 9 \\
\hline Formula & $\mathrm{C}_{54} \mathrm{H}_{58} \mathrm{AgIN}_{6}$ & $\mathrm{C}_{35} \mathrm{H}_{41} \mathrm{ClN}_{3} \mathrm{Rh} \cdot 0.5 \mathrm{CH}_{2} \mathrm{Cl}_{2}$ & $\mathrm{C}_{35} \mathrm{H}_{41} \mathrm{BF}_{4} \mathrm{~N}_{3} \mathrm{Rh}$ & $\mathrm{C}_{35} \mathrm{H}_{41} \mathrm{~N}_{6} \mathrm{Rh}$ & $\mathrm{C}_{30} \mathrm{H}_{29} \mathrm{BF}_{4} \mathrm{~N}_{3} \mathrm{O}_{2} \mathrm{Rh} \cdot \mathrm{CH}_{2} \mathrm{Cl}_{2}$ \\
\hline$F_{\mathrm{w}}$ & 1025.83 & 684.53 & 693.43 & 648.65 & 726.20 \\
\hline Crystal system & Monoclinic & Triclinic & Monoclinic & Monoclinic & Monoclinic \\
\hline$a(\AA)$ & $11.93060(10)$ & $9.9510(1)$ & $11.3879(2)$ & $19.1836(2)$ & $7.6849(1)$ \\
\hline$b(\AA)$ & $26.0899(3)$ & $11.1440(2)$ & $17.4662(4)$ & $9.7555(1)$ & $20.0418(3)$ \\
\hline$c(\AA)$ & $17.1421(2)$ & $16.9640(2)$ & $17.7733(3)$ & $19.6249(2)$ & $21.0343(3)$ \\
\hline$\gamma\left({ }^{\circ}\right)$ & 90 & $113.683(1)$ & 90 & 90 & 90 \\
\hline$V\left(\AA^{3}\right) ; Z$ & $5060.05(9) ; 4$ & $1648.56(4) ; 2$ & $3350.8(1) ; 4$ & $3214.21(6) ; 4$ & $3237.05(8) ; 4$ \\
\hline$d_{\text {calc. }}\left(\mathrm{Mg} / \mathrm{m}^{3}\right)$ & 1.347 & 1.379 & 1.375 & 1.340 & 1.490 \\
\hline$F(000)$ & 2096 & 710 & 1432 & 1352 & 1472 \\
\hline Crystal size $\left(\mathrm{mm}^{3}\right)$ & $0.15 \times 0.12 \times 0.10$ & $0.25 \times 0.20 \times 0.15$ & $0.35 \times 0.25 \times 0.15$ & $0.25 \times 0.20 \times 0.15$ & $0.25 \times 0.20 \times 0.15$ \\
\hline Reflections collected & 29659 & 13174 & 17338 & 23363 & 18682 \\
\hline Goodness-of-fit on $F^{2}$ & 1.040 & 0.996 & 0.987 & 1.017 & 1.066 \\
\hline$R$ indices $[I>2 \sigma(I)]$ & $\begin{array}{l}R_{1}=0.0570 \\
w R_{2}=0.1366\end{array}$ & $\begin{array}{l}R_{1}=0.0338 \\
w R_{2}=0.0877\end{array}$ & $\begin{array}{l}R_{1}=0.0442 \\
w R_{2}=0.1267\end{array}$ & $\begin{array}{l}R_{1}=0.0386 \\
w R_{2}=0.0944\end{array}$ & $\begin{array}{l}R_{1}=0.0468 \\
w R_{2}=0.1288\end{array}$ \\
\hline
\end{tabular}




\section{Acknowledgement}

We thank the National Science Council, Taiwan, ROC for the financial support (NSC94-2113-M-002-035).

\section{Appendix A. Supplementary material}

Crystallographic data (excluding structure factors) for the structure reported in this work have been deposited with the Cambridge Crystallographic Data Center: CCDC nos. 295075 (complex 5), 295076 (complex 8), 295077 (complex 7), 295078 (complex 6) and 295079 (complex 9). Copies of this information can be obtained free of charge and by application to CCDC, 12 Union Road, Cambridge CB2 1EZ, UK, fax: +44 1223336 033, e-mail: deposit@ ccdc.cam.ac.uk or www: http://www.ccdc.cam.ac.uk. Supplementary data associated with this article can be found, in the online version, at doi:10.1016/j.jorganchem.2006. 06.004

\section{References}

[1] A.J. Arduengo III, R.L. Harlow, M. Kline, J. Am. Chem. Soc. 113 (1991) 361.

[2] M. Regitz, Angew. Chem., Int. Ed. Engl. 35 (1996) 725.

[3] A.J. Arduengo III, J.R. Goerlich, W.J. Marshall, J. Am. Chem. Soc. 117 (1995) 11027.

[4] (a) R.W. Alder, P.R. Allen, M. Murray, A.G. Orpen, Angew. Chem., Int. Ed. Engl. 35 (1996) 1121;

(b) R.W. Alder, C.P. Butts, A.G. Orpen, J. Am. Chem. Soc. 120 (1998) 11526

[5] (a) W.A. Herrmann, M. Elison, J. Fischer, C. Köcher, G.R.J. Artus, Chem. Eur. J. 2 (1996) 772;

(b) W.A. Herrmann, C. Köcher, Angew. Chem., Int. Ed. Engl. 36 (1997) 2162.

[6] M.J. Green, K.J. Cavell, B.W. Skelton, A.H. White, J. Organomet. Chem. 554 (1998) 175.

[7] D. Bourissou, O. Guerret, F. Gabbä̈, G. Bertrand, Chem. Rev. 100 (2000) 39, and references therein.

[8] C.M. Crudden, D.P. Allen, Coord. Chem. Rev. 248 (2004) 2247, and references therein.

[9] (a) D.S. McGuinness, K.J. Cavell, Organometallics 19 (2000) 741; (b) A.A. Danopoulos, S. Winston, M.B. Hursthouse, J. Chem. Soc., Dalton Trans. (2002) 3090;

(c) N.M. Scott, R. Dorta, E.D. Stevens, A. Correa, L. Cavallo, S.P. Nolan, J. Am. Chem. Soc. 127 (2005) 3516.

[10] (a) W.A. Herrmann, L.J. Goossen, M. Spiegler, Organometallics 17 (1998) 2162;

(b) S.A. Mungur, S.T. Liddle, C. Wilson, M.J. Sarsfield, P.L. Arnold, Chem. Commun. (2004) 2738;

(c) L.G. Bonnet, R.E. Douthwaite, Organometallics 22 (2003) 4187;

(d) A.A.D. Tulloch, A.A. Danopoulos, R.P. Tooze, S.M. Cafferkey, S. Kleinhenz, M.B. Hursthouse, Chem. Commun. (2000) 1247; (e) S. Gründemann, A. Kovacevic, M. Albrecht, J.W. Faller, R.H. Crabtree, Chem. Commun. (2001) 2274;

(f) S. Gründemann, A. Kovacevic, M. Albrecht, J.W. Faller, R.H. Crabtree, J. Am. Chem. Soc. 124 (2002) 10473;

(g) S. Dastgir, K.S. Coleman, A.R. Cowley, M.L.H. Green, Organometallics 25 (2006) 300;

(h) K.S. Coleman, H.T. Chamberlayne, S. Turberville, M.L.H. Green, A.R. Cowley, Dalton Trans. (2003) 2917;

(i) L.G. Bonnet, R.E. Douthwaite, R. Hodgson, J. Houghton, B.M. Kariuki, S. Simonovic, Dalton Trans. (2004) 3528.

[11] (a) A.A. Danopoulos, S. Winston, T. Gelbrich, M.B. Hursthouse, R.P. Tooze, Chem. Commun. (2002) 482;

(b) N. Tsoureas, A.A. Danopoulos, A.A.D. Tulloch, M.E. Light, Organometallics 22 (2003) 4750;

(c) H.M. Lee, P.L. Chiu, J.Y. Zeng, Inorg. Chim. Acta 357 (2004) 4313;

(d) S. Gischig, A. Togni, Organometallics 24 (2005) 203.

[12] (a) A.W. Waltman, R.H. Grubbs, Organometallics 23 (2004) 3105; (b) P.L. Arnold, M. Rodden, K.M. Davis, A.C. Scarisbrick, A.J. Blake, C. Wilson, Chem. Commun. (2004) 1612;

(c) P.L. Arnold, A.C. Scarisbrick, Organometallics 23 (2004) 2519;

(d) A.R. Chianese, R.H. Crabtree, Organometallics 24 (2005) 4432;

(e) B.E. Ketz, A.P. Cole, R.M. Waymouth, Organometallics 23 (2004) 2835;

(f) E. Mas-Marzá, M. Sanaú, E. Peris, Inorg. Chem. 44 (2005) 9961.

[13] (a) C. Köcher, W.A. Herrmann, J. Organomet. Chem. 532 (1997) 261

(b) S.-T. Liu, T.-Y. Hsieh, G.-H. Lee, S.-M. Peng, Organometallics 17 (1998) 993;

(c) R.-Z. Ku, J.-C. Huang, J.-Y. Cho, F.-M. Kiang, K.R. Reddy, Y.-C. Chen, K.-J. Lee, J.-H. Lee, G.-H. Lee, S.-M. Peng, S.-T. Liu, Organometallics 18 (1999) 2145;

(d) K.H. Park, S.Y. Kim, S.U. Son, Y.K. Chung, Eur. J. Org. Chem. (2003) 4341;

(e) K.L. Tan, R.G. Bergman, J.A. Ellman, J. Am. Chem. Soc. 124 (2002) 3202;

(f) M.T. Zarka, M. Bortenschlager, K. Wurst, O. Nuyken, R. Weberskirch, Organometallics 23 (2004) 4817;

(g) R. Dorta, E.D. Stevens, S.P. Nolan, J. Am. Chem. Soc. 126 (2004) 5054

(h) V. César, S. Bellemin-Laponnaz, H. Wadepohl, L.H. Gade, Chem. Eur. J. 11 (2005) 2862;

(i) S.-T. Liu, K.R. Reddy, Chem. Soc. Rev. 28 (1999) 315.

[14] H.M. Wang, I.J.B. Lin, Organometallics 17 (1998) 972.

[15] A.J. Arduengo III, H.V.R. Dias, J.C. Calabrese, F. Davidson, Organometallics 12 (1993) 3405.

[16] (a) M.V. Baker, S.K. Brayshaw, B.W. Skelton, A.H. White, Inorg. Chim. Acta 357 (2004) 2841;

(b) M. Laubender, H. Werner, Angew. Chem., Int. Ed. Engl. 37 (1998) 150

(c) Z.G. Aliev, L.O. Atovmyan, O.V. Golubeva, V.V. Karpov, G.I. Kozub, Zh. Strukt. Khim. 18 (1977) 336.

[17] C. Bianchini, W. Oberhauser, A. Orlandini, C. Giannelli, P. Frediani, Organometallics 24 (2005) 3692.

[18] C. Pettinari, F. Marchetti, R. Pettinari, A. Pizzabiocca, A. Drozdov, S.I. Troyanov, V. Vertlib, J. Organomet. Chem. 688 (2003) 216.

[19] B.R. James, D. Mahajan, Can. J. Chem. 58 (1980) 996, and references therein. 